John R. SOMMERFELDT, Bernard of Clairvaux: On the Spirituality of Relationship, New York - Mahwah NJ 2004, The Newman Press, ss. 178.

To już kolejna $\left(\operatorname{trzecia}^{3}\right.$ ) książka Johna R. Sommerfeldta, profesora historii na Uniwersytecie w Dallas (Teksas, USA). Tym, którzy nie znają postaci profesora, trzeba tylko uzmysłowić, że mają do czynienia z charyzmatycznym twórcą i organizatorem słynnych już Międzynarodowych Kongresów Mediewistycznych w Kalamazoo na Uniwersytecie Zachodniego Michigan, które każdego roku sprowadzają badaczy $\mathrm{z}$ rożnych dziedzin naukowych $\mathrm{z}$ całego świata, dając im możliwość wymiany doświadczeń i nowych poglądów. On sam jest szczególnie zaangażowany w działalność Mediewistycznego Instytutu, który organizuje coroczne Kongresy Studiów Cysterskich, stanowiących element składowy Kongresów w Kalamazoo. Związek prof. Sommerfeldta ze środowiskiem naukowym Kalamazoo thumaczy jego wieloletnie (1958-1978) pełnienie na tamtejszym Uniwersytecie (West Michigan University) funkcji profesora historii.

Tytuł obecnej książki, jak również jego poprzednie publikacje, wskazują na kierunek zainteresowań profesora. Koncentruje się on wokół problematyki cysterskiej, a szczególnie postaci i twórczości św. Bernarda z Clairvaux. Niniejsza książka pt. Bernard $z$ Clairvaux: $O$ duchowości relacji, ma za zadanie ukazać niepowtarzalny fenomen wielkiego reformatora cysterskiego w prowadzeniu spraw doczesnych Kościoła i państwa zgodnie z Bożym planem zbawienia. Książka, oprócz części zasadniczej, została poprzedzona Wykazem skrótów, Wstępem, a zakończona Przypisami, Bibliografiq i Indeksem rzeczowym.

$\mathrm{Na}$ właściwą część dzieła składa się dziewięć rozdziałów. Pierwszy zatytułowany: Bernard, społeczenstwo i Kościót (Bernard, Society, and the Chrurch) sytuuje Bernarda na tle epoki $\mathrm{z}$ uwzględnieniem jego wielowymiarowego wpływu na społeczeństwo ówczesnej Europy: królestwa, księstwa, na politykę Kościoła, religię i duchowość (w tym organizowanie wyprawy krzyżowej), naukę, sztukę, itp. Autora zastanawia w tym kontekście fakt, skąd u tego mnicha znalazł się tak potężny i wszechobecny wpływ na losy Europy, na co odpowiada: ponieważ jego życie i działalność zawierało wiele gotowych ideałów, z których wiele jeszcze nie miało skrystalizowanej formy aż do jego czasów (s. 3). Następnie po ogólnym przedstawieniu bernardyńskiej nauki o Kościele, która jest biblijną wizją umiłowanej nowej oblubienicy Jezusa Chrystusa (s. 4-6), autor podaje klucz do omówienia następnych rozdziałów (s. 6-12), a mianowicie potrójny porządek ówczesnego Kościoła. Widzi go jako przepra-

${ }^{3}$ Por. tytuły poprzednich publikacji J. Sommerfeldta: The Spiritual Teaching of Bernard of Clairvaux. An Intellectual History of the Early Cistercian Order, Kalamazoo 1991; Aelred of Rievaulx. Pursuing Perfect Happiness, New York - Mahwah NJ 2005; w przygotowaniu są następne dwie pozycje poświęcone duchowemu nauczaniu Bernarda i Aelreda. 
wiające się przez ocean trzy grupy ludzi symbolizowane w postaciach: Daniela, Noego i Hioba. Pierwsza grupa przeprawia się statkiem, druga mostem, trzecia przez bród. Pierwszą grupę stanowią ci, którzy dążą do doskonałości w ramach zgromadzeń zakonnych, będąc prowadzeni specjalnym pragnieniem doskonałości; drugą grupę ci, którzy zarządzają Kościołem ziemskim, tzn. duchowni (prałaci); trzecią - owczarnia ludu Bożego.

Zgodnie z tym rozróżnieniem, prof. Sommerfeldt w ramach drugiego rozdziału omawia „Monastyczny porzqdek Daniela” (Monastic Order of Daniel), opisując klasztor jako formę przedsmaku raju, praktykowane w nim cnoty oraz posługę ojcowską opata, który jest zarazem prałatem, a więc człowiekiem z grupy Noego. Tę grupę rozpatruje w trzecim rozdziale: „Duchowny porzqdek Noego" (The Clerical Order of Noah), prezentując jego biblijne obrazy oraz posługę rządzenia (pasterzowania), tj. służenia ludowi Bożemu, czy owczarni Bożej. Przedmiotem rozważań czwartego rozdziału, pt. „Wielość cnót Noego" (Noah's Many Virtues), są wielorakie cnoty kultywowane przez duchownych, a mianowicie: pokora, miłość do Boga i swej owczarni, hojna służebność, czystość i posłuszeństwo, pracowitość na niwie Pańskiej, sprawiedliwe i roztropne przewodnictwo, całkowite oddanie się sprawie Bożej.

Piąty rozdział omawia już stan świecki (Hioba) ludu Bożego (The Lay Order of $J o b$ ): błogosławieństwo otrzymane w życiu małżeńskim, zaangażowanie w świecie w ramach handlu, produkcji towarów i w innych godziwych zawodach, w tym w rolnictwie i rzemiośle. Następny szósty rozdział zajmuje się strukturą świeckiej władzy w zakresie grupy Hioba (Job's Ministry of Governance), omawiając po kolei ich władców jako: wasali (lenników) Pańskich i ministrów Boga, sprawiedliwych panujących, obrońców pokoju, krzyżowców, panów o wysokim morale. Na tle świeckiej grupy Hioba wyraźnie zaznaczają się tzw. dysydenci, czyli heretycy i poganie, muzułmanie i żydzi, o których traktuje siódmy rozdział.

Ostatnie dwa rozdziały mają charakter raczej wniosków końcowych, w których autor stawia pytanie o naturę podanego przez Bernarda podziału społeczeństwa, szczególnie jego hierarchiczności oraz występujących tu pozornych sprzeczności. W pierwszym przypadku (Daniel, Noah and Job: A Hierarchy?) widzi w nim duchową hierarchię cnót, powołania, „wyższości” (superiority) stanu duchownego oraz ,niższości” (lowly) stanu świeckiego, biorąc za punkt wyjścia cel królestwa niebieskiego. W drugim przypadku (Resolving Some Apparent Inconveniecies), autor opisuje pozorną sprzeczność w działalności Bernarda: $\mathrm{z}$ jednej strony jego wszechobecne zaangażowanie się w sprawy doczesne, $z$ drugiej kategoryczny zakaz, jaki sam skierował do swych mnichów, by nie mieszali się w politykę tego świata, ponieważ ich rolą jest modlitwa i kontemplacja. Bernard wykonywał te czynności $z$ nakazu papieża i z potrzeby chwili, jako duchowy przywódca ówczesnego świata (s. 114-123). Drugą dyskusyjną kwestią jest jego stosunek do sztuki i ornamentów stosowa- 
nych w kościołach, szczególnie tych monastycznych, które nie tyle mają zaspakajać próżną ciekawość, ile poprzez swoją prostotę mają kierować na Boga (s. 123-128).

Książka prof. J.R. Sommerfeldta jest twórczym wkładem w coraz lepsze poznanie i uznanie duchowego nauczania św. Bernarda. Ukazuje wielką erudycję autora i jego fachową orientację, zarówno w samych dziełach Opata z Clairvaux, jak i w publikacjach dotyczących jego osoby, o czym świadczy również bogata bibliografia zamieszczona na końcu książki. Żaden poważny badacz problematyki bernardyńskiej nie może nie znać tej pozycji, ukazuje ona bowiem społeczne myślenie Bernarda i jego duchowe korzenie. Usprawiedliwia tym samym jego, i jemu podobnych, zbyt duże zaangażowanie w sprawy doczesne wynikające ze szczególnego powołania i potrzeby Kościoła XII wieku.

Ks. Ryszard Groń - Chicago, USA

\section{John R. SOMMERFELDT, Bernard of Clairvaux. On the Life of the Mind, New York - Mahwah NJ 2004, The Newman Press, ss. 197.}

Profesor Historii Uniwersytetu w Dallas, twórca Międzynarodowych Kongresów Studiów Mediewistycznych w Kalamazoo, John R. Sommerfeldt, zaprezentował nakładem wydawnictwa Newman Press w Nowym Yorku, jedną z dwóch swych ostatnio napisanych książek, poświęconych św. Bernardowi z Clairvaux, pt. Bernard z Clairvaux. Życie umystu. Wystarczy tu przypomnieć, że jest on obecnie jednym z najbardziej kompetentnych pisarzy amerykańskich $\mathrm{w}$ dziedzinie studiów mediewistycznych, a szczególnie działalności i twórczości wielkiego reformatora cysterskiego XII wieku - św. Bernarda z Clairvaux. Obecna publikacja jest dedykowana zmarłemu Jean Leclercq'owi, jako hołd wdzięczności autora za wszelkie odkrycia tego francuskiego badacza w dziedzinie mediewistyki i za swe duchowe prowadzenie. Sommerfeldt wyjaśnia we Wstępie swe duchowo-naukowe kontakty z Leclercq'iem i inspiracje tego ostatniego $w$ dalszych badaniach nad nauką, a szczególnie epistemologią, Bernarda z Clairvaux, której generalnie książka jest poświęcona (s. VII; XV-XVII).

$\mathrm{Na}$ prezentowaną publikację składa się dziewięć rozdziałów poprzedzonych Wykazem skrótów i krótkim Wstępem autora oraz zakończonych Przypisami, Bibliografia i Spisem treści. Całość skupia się wokół dziewiczej dotychczas problematyki epistemologicznej Bernarda, czyli zagadnieniu form poznania i ich zadań. Rozdział pierwszy, pt. Bernard $i \dot{z} y c i e$ umyshu (Bernard and the Life of the Mind), stanowi tu swoisty klucz podziału całej pracy. Najpierw autor wprowadza i wyjaśnia o co mu chodzi: o poznanie w sensie osiągania szczęśliwości bycia z Bogiem (Centrality of Epistemology). Wyróżnia przy tym formy 